\section{Dariusz Dziadosz}

Katolicki Uniwersytet Lubelski Jana Pawła II w Lublinie dariuszdzi@op.pl

ORCID: 0000-0002-5191-0560

DOI: http://dx.doi.org/10.12775/BPTh.2019.009

\section{Biblica}

et

Patristica

Thoruniensia

12 (2019) 2: 159-189

ISSN (print) 1689-5150

ISSN (online) 2450-7059

\title{
The Circumcision of the Heart as a Deuteronomic Metaphor of Religious Identity of an Israelite
}

\section{Obrzezanie serca deuteronomiczną metaforą religijnej tożsamości Izraelity}

\begin{abstract}
Circumcision is an ancient practice used in many civilizations of the Fertile Crescent and an important reference point in determining the social position and religious identity of members of royal and priestly families, as well as men from lower social classes. Nevertheless, the Israelites who made it an external sign and, later, the necessary condition of belonging to the Mosaic religion, contributed most to the deepening and spreading of the theological aspect of circumcision (Gen 17:4; 1 Macc $1: 15,48,60-61)$. The order of the circumcision of the heart from Dt. 10:16 and 30:6 is the consequence of the theological re-reading of this ancient practice, which was undertaken by the religious circles of the post-exile era under the influence of the painful experiences of Babylonian captivity and the serious crisis of Jahvist monotheism which appeared in the seventh and sixth centuries before Christ. The appeal for circumcision of the heart is a new definition of piety based on the most important commandment of Deuteronomic theology, that is, the commandment of love of $\mathrm{YHWH}$ with all my heart and soul (Dt. 6:4-5), and consequently, an encouragement to cultivate a personal relationship with God modeled on the patriarchs, which is based on obedience to God's law in exchange for His blessing and support (Dt. 6:6-12, 11:18-25, 32:46).
\end{abstract}

Streszczenie: Obrzezanie to starożytna praktyka stosowana w wielu cywilizacjach Żyznego Półksiężyca i ważny punkt odniesienia w określaniu pozycji społecznej i tożsamości religijnej członków rodów królewskich i kapłańskich, a także mężczyzn z niższych warstw społecznych. Do pogłębienia i promocji teologicznego aspektu obrzezania najmocniej przyczynili się jednak Izraelici, którzy uczynili z niego zewnętrzny znak, a z czasem niezbędny warunek przynależności do religii mojżeszowej ( $\mathrm{Rdz} 17,4$; 1 Mch 1,15.48.60-61). Nakaz obrzezania serca, o którym mowa w Pwt 10,16; 30,6, jest konsekwencją teologicznej relektury tej starożytnej praktyki, którą podjęły religijne kręgi epoki powygnaniowej, pod wpływem bolesnych doświadczeń niewoli babilońskiej oraz poważnego kryzysu monoteizmu jahwistycznego, jaki zrodził się w VII 
i VI wieku przed Chr. Apel o obrzezanie serca to nowa definicja pobożności żydowskiej oparta na najważniejszym przykazaniu teologii deuteronomicznej, czyli nakazu miłości JHWH z całego serca i całej duszy (Pwt 6,4-5), a w konsekwencji, to zachęta do kultywowania osobistej relacji z Bogiem na wzór patriarchów, której podstawą jest posłuszeństwo wobec nakazów Bożego prawa w zamian za Jego błogosławieństwo i wsparcie (Pwt 6,6-12; 11,18-25; 32,46).

Keywords: circumcision; heart; Deuteronomy; Deuteronomic theology; the Sinai covenant.

Słowa kluczowe: obrzezanie; serce; Powtórzone Prawo; teologia deuteronomiczna; przymierze synajskie.

Circumcision, or the surgical removal of the male foreskin, ${ }^{1}$ is an archaic rite which is practiced today by Jews, Muslims, as well as many other ethnic and religious groups, especially in Africa, South America and the Near East. According to biblical (Gen 17:9-14, 23-27, Ex 4:24-26,12,44, Lev 12:3; Jer 9:24-25) and extra-biblical sources, ${ }^{2}$ it can be assumed that this culturally and religiously conditioned ritual was born and developed in the ancient Near East. ${ }^{3}$ Relying on the artifacts and written sources available today, it is accep-

1 In many countries of the world, especially in Indonesia, Egypt, Somalia, Mali, Sierra Leone, Sudan, Ethiopia and other countries of Africa, circumcision of girls and young women is also practiced (the so-called excision, clitoridectomy). This habit - due to its invasive nature - should, however, be described as ritual mutilation of the female genital organs (FGM - female genital mutilation). This reprehensive practice has no medical or religious justification (it is not recommended by the Bible, the Koran, or other religious writings), and yet it has been and still remains culturally accepted in many communities. According to the statistics of UNICEF, in 2016, there were app. 200 million women in 30 countries around the world who were subjected to this cruel ritual. It is supposed that its cradle was Egypt, although neither the texts nor Old Egyptian iconography inform about it.

A. Krzemińska, Zwyczaj czy zbrodnia, Polityka [Accessed 9.01.2018] (www.polityka.pl/ tygodnikpolityka/nauka/1733292,1,skad-sie-wziela-tradycja-obrzezania-kobiet.read).

2 Ancient historians, such as: Flavius Josephus (Antiquitates Judaicae, 1,12.2; 13,257258), Philo of Alexandria (De circumcisione, 11,210) or Herodotus (Historiae, II, 36-37.104), listed, among others, Ethiopians, Egyptians, Phoenicians, Syrians from Palestine, Parthians and Arabs as peoples who practiced circumcision. See N. Livesey, Circumcision, pp. 34-58; M. Baraniak, Na ciele czy w duszy?, p. 79.

3 The oldest Near Eastern text on circumcision originates from the Egyptian stele of Naga ed-Der (circa 2300 BC). Its anonymous hero speaks of undergoing this procedure together with 120 royal sons (members of the royal court?) in the context of undertaking tasks related to ruling and priesthood. D. Dunham, Naga-ed-Der Stelae of the First Intermediate 
ted that circumcision was already a strictly defined socio-cultural phenomenon in Egypt at the end of the third millennium BC. Already at that time, the unique social and religious status and irreplaceable role of rulers and priests as well as their close relation with the gods was emphasized. Relying on Jer 9:24-25 it can be assumed that in subsequent centuries, circumcision became a practice used in many civilizations of the Fertile Crescent and it served as an important reference point in determining the social position and religious identity of men from the lower social classes. Nevertheless, the Israelites who made it an external sign and, in time, the necessary condition of belonging to the Mosaic religion, contributed most to the deepening and spreading of the theological aspect of circumcision (Gen 17:4; 1 Macc 1:15,48,60-61; cf. Acts 7:8; Rom. 2:25-29; 3:1-4; 4:9-12; 1Cor 7,18; Gal 2:11-14; 6:12-13; Phil 3:2-6). Over the turbulent history of Israel, this rite was perceived in a different way, and its cultural and religious significance continued to evolve. In some periods circumcision was a source of pride for the Israelites because it functioned as a sign of their close relationship (covenant) with $\mathrm{YHWH}$ and belonging to His chosen people. ${ }^{4}$ But there were also periods when it was deliberately ignored and overlooked because of persecution or growing unbelief (1 Macc 1:15,48). In defining the religious aspect of circumcision the turning point was the period after the Babylonian captivity marked by the collapse or permanent crisis of the most important socio-political and religious institutions in Israel. At that time those in exile or the Israelites returning from it decided to rebuild their cultural and religious identity by rebuilding the temple, restoring the mono-

Period, pp. 102-104; Ancient Near Eastern Texts Relating to the Old Testament, p. 326. Funeral texts from the $12^{\text {th }}$ Dynasty period (circa $2134-1786$ BC) confirm this type of practices at the royal court and in the priestly circles of Egypt. Thus it can be assumed that circumcision was at some stages of the history of Egypt a ritual introducing to the office of the king-priest. R. de Vaux, Instytucje, p. 57; F. Jonckheere, La circonsion, p. 214.

4 The Hebrew Bible describes circumcision or the absence of it using 6 lexemes: $m w l$ "circumcise", $m l l$ "circumcise", mûlâ "circumcision", ' $r l$ "not to be circumcised, to have foreskin", 'orlâ "foreskin" i 'ārēl "to have foreskin, not to be circumcised". F. Brown, S. Driver, C. Briggs, The Brown-Driver-Briggs Hebrew and English Lexicon, pp. 557-558. The theme of circumcision is mentioned in Torah 40 times and in the prophetic texts 44 times. J. Derouchie, Circumcision in the Hebrew Bible and Targums, pp. 178-179; M. Fox, The Sign of the Covenant, pp. 557-596; W. Propp, Circumcision, pp. 22-29. In Gen 17:11 circumcision is called 'ôt berit the "sign of covenant", and in Gen 17:13 berit bibśarkem "convenant in your flesh". In Yiddish circumcision is known as bris, that is a modified form of the term $b^{e}$ rit "covenant". G. Buchanan, Obrzezanie, p. 574. During the early rabbinic period ( $1^{\text {st }}$ century $\mathrm{BC}-1^{\text {st }}$ century $\mathrm{AD}$ ), the circumcision on the eighth day after birth was a feast for the whole family (it could even take place on the Sabbath) and was accompanied by a solemn blessing and feast. 
theistic worship in Jerusalem (Ezra 6:1-22, Ne 13:15-22; Hag 1:1-2:23), as well as by practicing circumcision and keeping the Sabbath. ${ }^{5}$ The most important theological schools and writers began to speak about the need for a thorough spiritual renewal in Israel. All the groups responsible for the current shape of the Hebrew Bible, among others, deuteronomic and deuteronomistic circles as well as priests consistently advocated closer ties with YHWH, redefinition of the rules of the Sinai covenant and Yahwist monotheism, as well as giving sufficient importance to traditional forms of piety, including circumcision (Gen 17:1-27, Ex 4:24-26; Dt 10:16; 30:6; Josh 5:2-9). In the latter matter, the most significant and innovative are deuteronomic (deuteronomistic) texts, which no longer speak only about the obligation to circumcise the foreskin, but about the necessity of circumcision of the heart (Dt 10:16; 30:6; cf. Jer 4:4; 9:25). In the light of this theological interpretation, circumcision in the Bible becomes a metaphor. It is a universal symbol and sign for the Israelites (applies equally to all men and women), which is supposed to signify the wish of adhering to YHWH and entering into the close relationship of the covenants, repeated many times during their stay in the promised land.

Due to the importance and complexity of this issue, biblical texts on circumcision will be the subject of this article. Relying on the historical-critical and intertextual method of interpretation of the sources of the Hebrew Bible, the genesis and cultural-religious context of circumcision in Israel will first be presented against the background of similar practices used in the neighboring Near Eastern cultures. At the later stage of the research, two deuteronomical biblical traditions will be thoroughly analyzed, which clearly modify the original theological and cultural profile of the circumcision rite, suggesting the need for a deeper and more metaphorical understanding of it (Dt 10:16; 30:6). The detailed aim of the article is to define the religious and theological intentions which accompanied the editors of Deuteronomy, who during the period of major historical transformations in Israel proposed a completely new and exceptionally theological interpretation of the sign of circumcision to provoke the renewal of Yahwism.

5 The same ideas guided the Maccabees who, in the years 168-164 BC, defended the faith of the fathers and Israeli cultural identity by restoring the purity of the worship, the Sabbath and the circumcision (1 Macc 2:38-41,46; 4:36-61), as well as the Bar -Kokhba insurgents (132-135 AD) who rebelled against the Emperor Hadrian due to the introduction of the prohibition of circumcision. 


\section{The rite of circumcision in the cultural and religious context of Israel}

The analysis of extra-biblical literature and artifacts $^{6}$ and biblical sources ${ }^{7}$ leads to the conclusion that male circumcision was one of the oldest and most-widely used surgical interventions in the Near East. ${ }^{8}$ The genesis, form and original meaning of this rite are still the subject of lively discussions among historians and exegetes. Some emphasize the cultural aspect of circumcision, ${ }^{9}$ others look for its deeper social and religious-cultic ${ }^{10}$ implications, suggesting that from the

6 The oldest discovery confirming the circumcision rite in the ancient Near East are three figures of warriors originating from northern Syria (the 'Amuq Valley), which date back to 2800 BC. Two of them show circumcision typical of Israel (total removal of the foreskin). J. Sasson, Circumcision in the Ancient Near East, pp. 475-476; R. Steiner, Incomplete Circumcision, pp. 497-505. On the basis of this finding, some historians suggest that circumcision was born in western Mesopotamia, and then through northern Syria moved to Egypt. According to this theory, the Israelites took over the rite in the form in which it was practiced in Syro-Palestine (cf. Josh 5:2-9). J. Meade, The Meaning of Circumcision, pp. 35-37.

7 In 9:24-25, Jeremiah in the form of the oracle of YHWH predicts the punishment of God 'al-kol-mûl be 'orlâ "for all circumcised only in the flesh", to which he includes the inhabitants of Egypt, Judah, Edom, Ammon, Moab. The reason for the punishment is an unspecified fault described in case of foreign peoples by the expression 'ărēlìm "uncircumcised", and in case of the Israelites as 'arlê-lēb "uncircumcised in heart". The expression 'ärēl "uncircumcised" has a pejorative connotation in the Hebrew Bible and is often used in relation to the Philistines, the fervent enemy of Israel, who as one of the few neighbors of Israel (cf. Shechemites in Gen 34:13-24) did not practice circumcision (Judg 14:3; 15:18; 1Sm 14:6; 17:26,36; 31:4; 2Sm 1:20). R. Gordon, I and II Samuel, p. 137; R. Klein, 1Samuel, p. 136. Later, the expression 'ârēl in the Bible was used to define a man (nation) wicked and ungodly who will be abandoned by YHWH and will remain in Sheol (Eze 32:28).

8 The archaic nature of this custom in Israel can be demonstrated, for example, by the order to circumcise Hebrew babies harbôt șürim with the use of flint (stone) knives" (Josh 5:2; cf. Ex 4:25).

9 In Egypt and initially perhaps in Israel, circumcision was a rite which introduced the young man into adulthood. According to some, it took place the day before the marriage as a sign of recognition of readiness to start a sexual life (fertility ritual cf. Gen 34:13-24). P. King, Circomcision, p. 50; J. Meade, Circumcision of the Heart, pp. 63-64; J. Sasson, Circumcision in the Ancient Near East, p. 474; H. Forshey, Circumcision, pp. 150-158. Others emphasize the apotropaic aspect (protection against the evil power of demons; (cf. Ex 4:2426), cultural (Gen 34:13-24) or health and hygienic reasons for circumcision. R. Hall, Circumcision, p. 1026.

10 According to some, when the covenant was made with YHWH on Sinai, the Israelites adopted the Egyptian rite of circumcision of priests as a sign of religious initiation. G. Foucart, Circumcision, p. 675; E. James, Initiatory Rituals, p. 155. 
beginning it has functioned as a sign of entering into a special bond (affiliation) with the world of gods (e.g. with God Ra in Egypt) and opened the way to the highest functions (e.g. king-priest). ${ }^{11}$ Although circumcision - in the sense of a practice with a clear religious and cultural profile - was and still is associated primarily with Judaism, it is not an invention of the Israelites. The most probable cradle of the rite is Egypt, ${ }^{12}$ but Mesopotamia ${ }^{13}$ and Syro-Palestine ${ }^{14}$ are also considered to be the place where circumcision was first practiced. However, it was the Israelites who gave it the richest theological significance, which is considered both in relation to the circumcised, as well as his family (clan) and the entire ethnic community. According to Gen 17:1-27, Abraham was the first patriarch who, by the will of God, introduced circumcision to Israel. ${ }^{15} \mathrm{His}$ connections with western Mesopotamia, Egypt and Canaan described in the

11 Assuming that in Egypt circumcision was a manifestation of the pharaoh's divine origin and the external sign of his unique bond (covenant) with god (gods), some scholars see the similar genesis of circumcision in Israel. In this vein, the tradition of Ex 4:22-23,2426, which first defines Israel's relationship to YHWH in the key of relationship: father - the firstborn son, then speaks of the circumcision of Gershom by Zipporah and the mysterious ritual of touching his sex organs with the son's foreskin. J. Meade, The Meaning of Circumcision, p. 44; E. James, Initiatory Rituals, p. 157; S. Hoenig, Circumcision, pp. 322-334; E. Isaac, Circumcision, pp. 444-456.

12 A serious argument challenging this thesis is the ritual technique described (illustrated) by artifacts from the country of the pharaohs. Egyptian circumcision consisted in a partial removal or incision of the foreskin, and the Hebrews practiced its complete removal. Egyptian literature, iconography and preserved artifacts (e.g. mummies) prove that circumcision was not practiced at all stages of the Egyptian history. The Egyptians did not circumcise all men, only those who were predestined to take on social and cultural functions. They did not do it in their childhood, like the Israelites (Gen 17:12; Ex 4:25; Lev 12:3). R. de Vaux, Instytucje, p. 56; J. Meade, The Meaning of Circumcision, pp. 38-40.45-48; W. Propp, The Origins of Infant Circumcision, pp. 355-370.

13 J. Sasson, Circumcision in the Ancient Near East, p. 474; R. Steiner, Incomplete Circumcision, p. 503; J. Meade, The Meaning of Circumcision, pp. 36-37; J. Derouchie, Circumcision in the Hebrew Bible and Targums, p. 187; F. Jonckheere, La circonsion, p. 228. These opinions have only a hypothetical value. So far, no traces of circumcision have been found in eastern Mesopotamia (Assyria and Babylonia). G. Mayer, mûl, p. 159.

14 R. Hall, Circumcision, p. 1025. From the point of view of the topography of biblical texts, it is possible to observe that the circumcision of Abraham and all men in his home (Gen 17:23), and the first collective circumcision of the Israelites (Josh 5:2-9) took place in Canaan, which might suggest that they adopted this custom from the Semitic inhabitants of Syro-Palestine.

15 The text of Gen 17:1-27 bears strong traces of theological elaborations made by the circles of priests, therefore the archaic and historical character of the events described in it arouses numerous doubts. The description of circumcision of Abraham and his relatives 
Bible (Gen 11:27-32; 12:1-20), however, may suggest each of these civilizations as a source of ritual. The source texts: Gen 34:13-24, Ex 4:24-26 and Josh 5:2-9 confirm that circumcision was practiced in Israel in the time of the oldest Patriarchs, and then in the time of Moses and Joshua, in Egypt and during the conquest of Canaan. The ritual and legal texts of the Hebrew Bible command to circumcise all male children on the eighth day after birth (Gen 17:12, 21:4, Lev 12:3), and the adult proselytes immediately before their inclusion into the Israelite community (Gen 17:23-27; 34:15-24; Josh 5:3-7). According to the Jewish tradition, the father of the family performed the procedure (Gen 21:4), on special occasions the mother (Ex 4:25) or a man specialized in this task (1 Macc 1:61).

The Hebrew Bible and the rabbinical tradition differently define the socioreligious status of the circumcised and uncircumcised, and their relationship to God and Israel. There are texts which grant all Jews, including the uncircumcised, the right to belong to the chosen people. Others firmly state that the absence of this sign excludes them from the fellowship and covenant with YHWH (Gen 17:14). Speaking of circumcision, the Hebrew Bible focuses on two basic arguments. On the one hand, it regulates legal and cultic issues of the rite, specifying the time, circumstances, effects and obligatory nature of circumcision (Gen 17:10-14, Ex 12:44, 48-49, Lev 12:3). On the other hand, it describes its course relying on the example of the leading figures of the chosen people, emphasizing the historico-salvific importance of these events (Gen 17:1-9, 23-27, Ex 4:24-26, Josh 5:2-9). From this theological perspective, for example, the priestly text of Gen 17:1-27 directly makes the connection between Abraham and his descendants with God from the moment of circumcision, and the much older source of the Ex 4:22-24, prepared by the priestly editor, suggests that without circumcision of Gershom, Moses would have to die because of the wrath of YHWH. The purpose of these narratives is obvious. They were to motivate the Israelites to cultivate the rite. The editor of Deuteronomistic historiography of Israel (Josh -2Kings) makes the Passover of the Hebrews led by Joshua (Josh 5:10-12, Ex 12:48) conditional on their submission to circumcision and in the further perspective it also applies to their military success in fighting for the land of Canaan (Josh 5:13-21:42).

in the context of the idea of a covenant with YHWH and God's promises (land and numerous offspring) is characteristic of the late literary etiology created in the post-exile period. 
It is difficult to establish precisely the time in which circumcision has become a universal and obligatory practice in Israel, ${ }^{16}$ but it is known that the priestly circles - responsible for the final version of the Torah - made sure that this rite would be a sign ('ôt) of the most important for the Israelites models of the religious covenant with YHWH. This primarily refers to the covenant of Abraham and his broadly understood offspring (Gen 17:12-13,27; 18:18-19), which was based on God's promise of land, numerous offspring and blessing (Gen 17:1-22), and the covenant in Sinai based on the promises and the law of YHWH revealed by Moses (Ex 12:44, 48-49; Lev 12:3). From the theological perspective of the priestly circles, circumcision gained a mnemonic and symbolic significance, ${ }^{17}$ as it allowed to transmit and consolidate in Israel the truth about the close bond of the Hebrews with YHWH, and, at the same time, reminded of the obligations originating from this fact. It must be emphasized, however, that already in the pre-priestly edition of the Hebrew Bible the religious circles of Israel took care of this ancient Near Eastern practice in Israel so that it would gain a profound religious meaning (ritual and ethical) which was far different from what was attributed to it in Egypt or Syro-Palestine. Thus, in Israel, circumcision was not reserved only to privileged social classes and associated only with the fulfillment of important public functions, but it applied to all men from the moment they were born (Lev 12:3). On the basis of legal regulations, the authorship of which is attributed by the Hebrew Bible to God and the most important patriarchs (Abraham and Moses), ${ }^{18}$ circumcision began to function as an external sign of belonging to the chosen people. This sign gave each Israelite the status of a son of God (Ex 4:22-24, 25-26), it made him the heir of the promise made to Abraham (Gen 17:1-14), it also placed in the sphere of the influence of God's blessing and confirmed the eternal bond of the covenant with YHWH. At the same time, it obliged to be loyal to God and to obey His law revealed on Sinai. Through circumcision the Israelites were obliged to imitate faith, faithfulness and obedience of Abraham and Moses, but

16 Gen 34:13-24 suggests that within some ethnic groups living in Canaan in the era of patriarchs (e.g. families of the sons of Jacob) circumcision was considered a sign of belonging to the clan.

17 This understanding of circumcision and covenant is indicated by the God of Israel in the moment of a close relationship with Abraham: "serve me faithfully and live a blameless life” (Gen 17:1). C. Westermann, Genesis 12-36, p. 265.

18 These legal and cultic norms began to apply probably only after the Babylonian captivity. The conclusion is drawn from the analysis of the historical context behind biblical texts on circumcision. All these texts were created in the priestly circles (Gen 17:1-27; Ex 12:48-49; Lev12:3), or were theologically rewritten (Ex 4:24-26). G. Mayer, mûl, p. 160; P. Williamson, Circumcision, p. 122. 
also it allowed them to worship YHWH in the land they received from Him (Josh 5:2-8). Such strong religious connotations of this rite were not found in any of the communities of the ancient Near East. ${ }^{19}$ In the post-exile period, circumcision in Israel became a religious and ethnic obligation (Gen 17:14; cf. 34:13-24), and its abandonment threatened with exclusion from the community, breaking the covenant with YHWH and His wrath (Ex 4: 24-26).

The tightening of legal regulations regarding circumcision was historically conditioned. ${ }^{20}$ In the Persian and later Hellenic period, the peoples of SyroPalestine began to depart from this practice (cf. Jdt 14:10, Est. 8:17), and the Israelites followed them. Although the historical and prophetic books of the Hebrew Bible do not speak about it directly, on the basis of the information provided in them, it can be assumed that the abandonment of this rite took place in Israel and Judah already in the period of divided monarchy, when they started to abandon Yahwist monotheism (2 Kings 17:7-23; 23:4-24; 24: 3-4). The cause of the growing crisis was the policy of religious syncretism promoted by successive rulers of both kingdoms, the weakness of religious elites (priestly and prophetic circles) and the low level of religious awareness in the people (Isa $1: 2-7,10-20 ; 2: 6-3: 15 ;$ Jr 4:4; 7:1-28; 9:1-8,24-25; Hos 4:1; 5:7; Am 2:4,6-12). This unfavorable process was additionally aggravated by the painful experiences of Assyrian and Babylonian captivity. In the face of the collapse of important places of worship and the crisis of religious structures in Israel and Judah, many Hebrews decided to abandon native traditions in favor of polytheistic patterns and attitudes which were adopted from the Mesopotamian and SyroPalestinian communities (Isa 58:13-59:15; Eze 36:16-32).

19 During the Hellenistic period, circumcision in Israel was seen as a way of manifesting the ethnic and cultural-religious separation of the Hebrews, and a way for foreigners to enter into the sphere of their monotheistic faith (Gen 34: 15-24; Ex 12:48, cf. Gen 17:27; 18: 19). In this way, those who were not the biological descendants of Abraham gained the opportunity to enter into the socio-religious structures of the chosen people and were granted the right to participate in the promises of YHWH. P. Williamson, Circumcision, pp. 123-124.

20 Through the new legislation and promotion of the model of life according to the faith and customs of ancestors, religious exile circles in Israel tried to rebuild the identity and piety of the chosen people, and at the same time emphasized its religious and ethnic separateness in the environment of Canaan's polytheistic communities. As a result of these reformatory actions, the Israelites in the Hellenistic period remained the only community in the region which practiced circumcision due to religious reasons, which, in time, contributed to the sacralization of this rite, so strongly emphasized in some biblical texts (Gen $17: 1-27)$. 
Another serious test for the practice of circumcision in Israel - this time already thoroughly described by the Books of the Maccabees - turned out to be a confrontation with Greek culture. The policy of repression introduced by the last king of the Seleucid dynasty - Antiochus IV Epiphanes, who in 169/168 BC plundered the temple in Jerusalem, turned it into the shrine of Syro-Phoenician Baal-Shamen, ${ }^{21}$ and then strictly forbade the observance of the Sabbath, circumcision and other Jewish traditions (1 Macc 1: 60-61; 2 Macc 6:10), again resulted in acts of apostasy and the departure of many Israelites from the religion of their fathers (1 Macc 1:15). This situation changed only after the armed uprising of the Maccabees, who defeated the invader and restored the traditions of Judaism, including circumcision in Israel (1 Macc 2:46).

In the context of circumcision, biblical sources speak of one more important issue. This time it is its doctrinal implied meaning, which was caused by the evangelizing activity of Jesus and His disciples. Until the end of the first century AD, Judeo-Christian and Christian circles continued lively discussions about the conditions which pagans had to fulfill in order to enter the Church community. Christ himself never directly took up the subject of circumcision, although he referred to the obligation to celebrate the Sabbath and other precepts of Jewish law (Luke 6:1-5:6-11). ${ }^{22}$ In His teaching, He repeatedly confirmed the value of Jewish tradition (Mtt 5:17-18), but he always reminded the Pharisees arguing with Him that the believers should focus on their spirit (God's will), not on the letter (Mtt 15:1-20 23:1-36: Mk 7:1-23). ${ }^{23}$ The dispute over circumcision erupts with all its impetus only in the period of the emerging Church (Acts 15:1-33; 16:3; Gal 2:3-5). A special role was played by evangelical and epistolary activity of Saul of Tarsus, who was converted from Judaism. The Apostle repeatedly emphasized the spiritual dimension of the rite of circumcision (1Cor 7:17-20), arguing that external practice alone does not determine the socio-religious identity of Israelite and does not provide him with a close and lasting relationship with God. He believed that a real Jew in the order of law is only one who consciously and zealously strives for spiritual fruits result-

21 J. Ciecieląg, Żydzi w okresie drugiej świątyni, pp. 200-201.

22 L. Cohick, , Judaizm, p. 331. According to the Mosaic law, Jesus was circumcised on the eighth day after his birth (Luke 2:21), just as his predecessor - John the Baptist (Luke 1:59). Regarding the first followers of Christ, the New Testament texts speak only of circumcision of Timothy - Paul's disciple, which occurred in quite controversial circumstances immediately before the beginning of the second missionary expedition of the Apostle of the Nations (cf. Acts 15:1-33 and 16:1-5).

23 Jesus' interpretation of law is based on the same theological foundations as the Deuteronomic interpretation of circumcision, which, in addition to the removal of the foreskin, also postulates the circumcision of the heart (Dt 10:16; 30:6; Jer 4:4). 
ing from the external sign of circumcision, which are, among others, the desire to constantly know and love God and to fulfill His will in everyday life (Rom 2:25-27): "A person is not a Jew who is one only outwardly, nor is circumcision merely outward and physical. No, a person is a Jew who is one inwardly; and circumcision is circumcision of the heart, by the Spirit, not by the written code. Such a person's praise is not from other people, but from God" (Rom 2:28-29).

According to Paul's theology, the practice of external circumcision in Israel was the will of YHWH only at a certain stage of its history. Thanks to the Gospel and the Passover of Christ this rite lost its power and does not have to be obeyed by Jesus' disciples because its value before God depended on the observance of the Mosaic law in its entirety, and no Israelite was able to do so (1Cor 7:17-20, Gal 2:7-3:14; 5:11-12; 6:13-15). ${ }^{24}$ Thus, the Jews and Gentiles who joined the Church were assured by Paul that Jesus released them from the circumcision and other precepts of the Mosaic law through offering a new, fully spiritual circumcision (a new creation), based on abandoning everything that disturbs from the communion with the Father, (Col 2:11-14). Instead of the rite of circumcision as a sign of the eternal covenant with God the Apostle in the name of Jesus indicates faith which acts through love (Gal 5:6; Phil 3:2-3).

\section{Theological Re-reading of the Rite of Circumcision in the Deuteronomic Theology}

The idea of spiritual circumcision, which Paul suggests to the Jews and Christians, is not the theological invention of New Testament literature. The religious circles of Israel have already emphasized the conditional value of circumcision in the eyes of God, which is not self-evident and does not depend on the exact fulfillment of the regulations related to the external ritual, but depends on faith

24 T. Schreiner, Obrzezanie, pp. 540-541; D. Stern, Komentarz żydowski, pp. 512-515; Obrzezanie, pp. 616-617. According to Paul's theology, circumcision has a value before God only when faithfulness to the recommendations of the Mosaic law goes hand in hand with it. Every circumcised who disregards this law is in the eyes of $\mathrm{YHWH}$ as an uncircumcised pagan. On the other hand, the lack of circumcision of a gentile who obeys the law of Moses does not hinder him from the possibility of a close relationship with YHWH and makes him equal in terms of socio-religious status with the circumcised Jew (Rom 2: 25-27). This interpretation of the rite is already presented by Jeremiah, who announces God's judgment and punishment for the circumcised only in the flesh for disobeying the commandments: "The days are coming," declares the LorD, "when I will punish all who are circumcised only in the flesh, but [are really] uncircumcised" (Jer 9:24). 
and obedience of the circumcised to YHWH during the period of the Deuteronomy edition. ${ }^{25}$ One of the last editors of the book - in a form of theological gloss - puts two texts in Moses' mouth (10:16: 30:6), which clearly redefine the previous (original) way of interpreting circumcision in the Jewish tradition, emphasizing its theological and spiritual meaning. ${ }^{26}$ The main research subject at this stage of the article will be the definition of the assumptions and purpose of this theological re-reading, as well as the mapping of the historical context in which it took place.

\subsection{The Circumcision of the Heart as a Duty Resulting from the Covenant with YHWH (Dt 10:16)}

To understand the theological sense of the Deuteronomist tradition (10:16) and its historico-salvific background, it is necessary to determine precisely the meaning of its nearest context, i.e. pericope 10:12-22. This text, communicating, among others, the idea of the circumcision of the heart is part of the autonomous section, which in the book is called hattôrâ 'ăšer-śám mōšeh "the laws that Moses gave" and by the exegetes it is called "the second speech of Moses" (4:44-11:32). In the current structure of the book, the "law of Moses" plays an important and strictly defined role, as it creates a theological foundation and gives the key to interpret its central section: the Deuteronomic law code (12:126:19). ${ }^{27}$ The block of tradition $4: 44-11: 32$ is one of three sections analogical

25 Jewish tradition attributes the entire book to Moses and considers it as the main interpretation of Jahwistic monotheism. The variety of sources and traditions included in the book, its complex form and literary structure, as well as extensive theology suggest, however, a long and multi-stage process of editing this work. Only some records in the legal code (12:1-26:19) may date back to the period of Moses in the form of an oral message, whereas its final form and the multi-level theological commentary edited in the shape of public appearances of the patriarch $(\mathrm{cf} .1: 1 ; 4: 44 ; 28: 1,69 ; 29: 1 ; 31: 1)$ is the work of the writers from the period of the reform of Josiah (31:9-13, cf. 2 Kings 22:1-23:30) and the time after the Babylonian captivity. P. Craigie, The Book of Deuteronomy, p. 20; C. Wright, Deuteronomy, pp. 6-8; R. Nelson, Deuteronomy, p. 4-8.

26 In a similar theological convention, the theme of circumcision is undertaken by the prophetic circles responsible for the editing of the Book of Jeremiah, who directly address the inhabitants of Judah and Jerusalem with the following appeal: himmōlu lJHWH we hāsirû "orlôt lebabkem "circumcise yourselves to the LORD, and take away the foreskins from your heart" (4:4). This attitude (the act of will) is based on a conscious avoiding of evil deeds to escape the consequences of God's wrath and punishment for the violation of His law.

27 In the key of the canonical reading of the Hebrew Bible, the multistage and multifaceted speech of Moses is related to the situation described in the last part of the Book of Numbers, which reports the arrival of the Hebrew tribes to the hills of Moab opposite 
in form and content (cf. 1:1-4:40; 4:44-11:32; 28:1-30:20), which in the way of the complex editing process received the form of public speeches of Moses. These three interventions in the current version of the book serve as a historico-salvific narrative which documents the presence of YHWH in the history of Israel from the beginning of the persecution by the pharaoh to the time of the territorial conquests in Canaan. These texts are, at the same time, a type of theological paradigm and moral sermon and show the importance of the covenant of Sinai and oblige Israel to respect its legal norms. Pericope 10:12-22 and recorded in 10:16-17, call for circumcision of the heart are focused on the most important message of all speeches of Moses, invoking the truth of YHWH's free and unwavering love to the Israelites revealed in Egypt and during the wandering through the desert, which demands of them an equally strong and lasting reaction. Faithfulness and obedience to YHWH are presented in the closest context of verses 10:16-17 as the most appropriate response of the Israelites: both to God's powerful and caring commitment to their recent past, as well as His promises related to their immediate future. YHWH's interventions restored their dignity and freedom (6:1-25), and then elevated them, as the only people of the earth to the position of the chosen nation and beloved community of YHWH, who was bound with Him through a lasting covenant $(7: 1-16)$ and is to obtain Canaan (7:17-9:6). In spite of the constant disbelief and betrayal of the Israelites in the desert (9:7-29), which the editor of the book expresses by a metaphor of the "stiff neck" (9:6,13; cf. Ex 32:9; 33:3,5; 34:9) and "hardened heart” (29:18, cf. Psalm 95:8; Jer 3:17; 7:24; 9:13; 11:8; 13:10; Eze 3:7; Bar 2:33), YHWH declares the irrevocability of previously made promises and the permanence of His love. ${ }^{28}$ In such a context of the broken and renewed covenant with God and the promise of the earth renewed by Him, the editor of the book though Moses addresses a series of intense incentives to the Israelites to submit to the will of YHWH (10:12-11:32), which according to him is expressed by the Deuteronomic law code (12:1-26:19). ${ }^{29}$

Jordan and Jericho and their logistical-military and religious-legal preparations for the conquest and settlement of Transjordan and Canaan (Num 22:1-36:13).

28 To emphasize this truth, the editor of the second speech by Moses refers in the last part of it to three important facts from the recent history of Israel: 1) the renewal of the covenant of Sinai after it was broken by the idol worship of the calf (9:7-29:2) the establishment of the worship of YHWH focused on the ark of the covenant and the priestly ministry of the family of Levi (10:1-9; and 3) God's command to conquer Canaan (10:10-11).

29 Defining the pattern of Yahwistic piety, the text suggests the motivations which Israel should follow in building relations with YHWH. It also recalls the consequences that they should take into account when fulfilling (God's blessing) and breaking (God's curse) legal norms established by God. 
The analyzed idea of circumcision of the heart (10:16) appears within these incentives of Moses (10:12-22), which the editor of the book gave the status and authority of the will of YHWH. Presentation of God's demands for Israel (10:12-11:32) is initiated by Moses' extended sermon (10: 12-13). It consists of a series of formulas expressed in Deuteronomic terminology which, in the tone of the solemn credo, define the character of the Israelites' relationship with YHWH and enumerate a list of their religious duties. In this part of the speech of Moses verses 10:12-13 function as a preamble, which emphasizes the obligatory character of religious-moral imperatives directed by God towards the people in sections 10:12-11:32 and in 12:1-26:19. ${ }^{30}$ Furthermore, they define the theological and legal basis of these orders. By specifying the essence of Israelite's piety in the light of the idea of "fear of YHWH" 31 characteristic of Deuteronomic theology, the editor of the book also invokes the principal practice of Judaism - circumcision. However, it does not focus - like most Old Testament texts - on the historico-salvific or cultural-legal aspects of the rite, but on its spiritual dimension. In 10:16-17, for the first time in the Hebrew Bible, God's command for the circumcision of the heart and not of a member of the Israelite appears. From now on, it functions as the essence of Yahwistic piety and an integral relationship with YHWH postulated by the covenant of Sinai (10:12-13).

In 10:16 (cf. 30:6) the theological dimension and the religious and spiritual effects of the circumcision of the heart are emphasized, but this passage does not explain exactly what this type of procedure (process) would consist in. The appeal of Moses indicates the metaphorical meaning of the circumcision of the heart, although the consequences of this procedure should have a real impact on the personal relationship of the Israelite with YHWH and a specific application in his attitude in life. In the light of 10:16, circumcision of the heart should be understood as an activity analogical to the actual circumcision (removal of the foreskin), but performed within the mental, volitional or emotional activity of a human being. According to such logic, the removal of the foreskin would be to get rid of all the obstacles preventing or hindering the unity with God.

30 Verse 12:1, with which the central section of the book, i.e. the Deuteronomic law code (12:1-26:19) begins, takes the literary function of the official introduction (preamble) to the following set of laws but in a much narrower sense. It is analogical to the passage 10:12-13. D. Block, Deuteronomy, pp. 301-303; P. Craigie, The Book of Deuteronomy, p. 215; S. Sherwood, Leviticus, Numbers, Deuteronomy, p. 260.

31 The Deuteronomic concept of piety is based on the idea of profound reverence, sincere submission and gracious love towards $\mathrm{YHWH}$, and is expressed in fidelity to God's law and covenant. In the Hebrew Bible, this theological concept finds the fullest resonance in Israel's Deuteronomic historiography (Josh-2Kings). J. McConville, The Book of Deuteronomy, pp. 182-183; S. Richter, Deuteronomistic History, p. 228. 
This new interpretation of the ritual is not a criticism of the traditional concept of circumcision or an appeal to abandon it. The circumcision of the heart should be understood in this biblical context in the category of an open postulate of a profound renewal of religious life in Israel. This postulate - probably created only in the post-exile period of the edition of the Book of Deuteronomy - became a call for serious theological reflection on the real meaning of the rite of circumcision practiced in Israel since the patriarchs (Gen 17:1-27; Ex 4: $24-26 ; 12: 44$, Lev 12:3) and religious and moral obligations arising from it. The significance of the presented interpretation of the circumcision rite is raised by the literary form of verses 10:16-17 and the subject of their immediate context carefully selected by the editor $(10: 12-22 ; 11: 1-32)$. Passage $10: 16-17$ possesses the status of God's will revealed directly by Moses (cf. 10:12), i.e. it belongs to the traditions of the Hebrew Bible which have unquestioned authority. All the indications included in the immediate proximity of 10:16-17 (cf. 10:1222 ; 11:1-32) relate to the duties of the Israelites towards YHWH, which they promised to obey on Sinai. For this reason, the theological and socio-cultural significance of the command of circumcision of the heart should discover these spiritual commitments of the chosen nation.

The theological basis for section 10:12-11:32 and the entire book (cf. 4:10; $5: 29 ; 6: 24 ; 10: 12 ; 14: 23 ; 17: 19 ; 28: 58 ; 31: 13)$ is the Deuteronomistic concept of the unique relationship of Israel to God, which is based on the biblical idea of fear ( $l^{e j i r}$ 'â 'et-JHWH 'élōhejkā "be afraid of YHWH, your God"). This fear is understood as a sincere attitude of reverence and respect, reserved only to the God of Israel, which originates from the personal experience of His unsurpassed glory and love. The circumcision of the heart and other commands of God, of which Moses reminds the Israelites in 10:12-11:32, are thus presented as a concrete illustration of this general principle. Their fear of YHWH should manifest itself in exemplary obedience (lāleket $b^{e} k o l-d^{e} r a \bar{k} k \bar{j} j w$ "walk in all His ways"; cf. 11:22), love ( $l^{e}$ 'ahăbâ 'ôtô "love Him”; cf. 11:1,13,22; 10:15,18-19), sincere and unconditional service (la 'ăbōd 'et-JHWH 'élōhejkā bekol-lebābkā $\hat{u} b^{e} k o l-n a p s ̌ s k a \bar{a}$ "serve the LORD, your God, with all your heart and with all your soul"; cf. 10:12; 11:13) and obeying commandments revealed through Moses (lišmōr 'et-mișwōt YHWH w $w^{e}$ 'et-huqqātājw 'ăšer 'ānōkî $m^{e} s ̦ a w w^{e} k \bar{a}$ hajjôm letôb lāk "keep requirements of the LORD, His decrees, His laws and His commands always for your own good"; cf. 11:1,8,13,22). ${ }^{32}$

32 According to some exegetes, the form and layout of the Israelites' duties towards God are a reflection of the language and content of socio-political agreements in the ancient Near East. P. Craigie, The Book of Deuteronomy, p. 204; M. Weinfeld, Deuteronomy, pp. 83-84; P. Gordon, Deuteronomy, pp. 115-116. 
The closest context of the command for the circumcision of the heart (10:16) is indicated by verses $10: 14-15$, which in the form of merism ${ }^{33}$ reveal the unfathomable and full power of YHWH over the entire universe, and then illustrate the specificity of His close relationship with Israel. According to the theological vision of Moses, the God of Israel - the Lord of heaven, earth and all creatures - chose one nation on earth to give it His love which has no spatial or temporal limits. ${ }^{34}$ The relationship of YHWH to Israel is defined by two synonymous verbs ḩăšaq "to love, to be in love, to long for, to be inclined to" 35 and 'āhēb "to love, to cherish". These terms express the biblical idea of God's choice and the resulting irrevocable predilection for the patriarchs of Israel and their descendants, which is one of the pillars of the Deuteronomic theology.

God's command of the circumcision of the heart (10:16), which from this theological perspective appears quite unexpectedly, ${ }^{36}$ is present in 10:12-22

33 Merism is a well-known rhetorical figure in the Hebrew Bible which, to express the universal and full dimension of the described reality, indicates its two extreme (opposing) components. Thus in Dt 10:14 (cf. Gen 1:1; 2:4a; Dt 28:23; 33:28; Judg 5:4; 2Sm 22:8) the expressions haššāmājim "heaven" and hā'āreș "earth" denote not only the two most important spheres of the world seen by people, but also "everything", "the entire existing world (universe)", "visible and invisible beings".

34 Text 10:15 refers to the first representatives of Israel ('ăbōtejkē "your fathers and patriarchs") and at the same time a generation of Hebrews, contemporary to Moses, during his speech on the highlands of Moab, which at that time was the last link in the generation chain of a chosen people awaiting the fulfillment of God's promises from Gen 12:1-3; 15:7; 28:13-15. What was missing in the full realization of the promises made by God to the patriarchs, which function in the Deuteronomic theology as a concrete and credible proof of the love of YHWH, was the land that Moses and the addressees of his speeches could already see from the highlands of Moab (1:1-5).

35 F. Scerbo, ȟšq, p. 102; P. Reymond, ḩšq, pp.159-160; G. Wallis, h̆šq, pp. 261-263.

36 Verse 10:16 in the light of theology of 10:12-11:32 suggests the superiority, or at least complementarity, of spiritual understanding and fulfillment of God's will over the external application of the Mosaic law. In reference to circumcision, it would not only mean the fulfillment of tradition and removal of the foreskin of Israelite's member, but also the circumcision of his heart, i.e. spiritual renewal of the relationship with YHWH. All this indicates the late origin of this passage. The re-interpretation of the original priestly tradition requiring the circumcision of all men in Israel as a sign of belonging to $\mathrm{YHWH}$ and the obtaining the right to participate in His promises (Gen 17:1-27; Ex 12:48-49) was made by the deuteronomic, deuteronomistic or prophetic circles responsible for the ultimate edition of the Book of Deuteronomy and the Book of Jeremiah (Jer 4:4; 9:24-25; 31:33, cf. Eze. 11:19; 36:26). A. Smith, The Book of Deuteronomy, p. 141. Some exegetes interpret 10:16-17 in the synchronic key, suggesting that the modification of the interpretation of circumcision was done by Moses himself before entering Canaan (Dt 1:1-5; 4: 44-49; 11:29-32). He saw that the Israelites treated circumcision as a rite without spiritual significance and considered it as 
as a religious imperative to create in the minds and hearts of the Israelites the desire for a firm response to the gifts of love and faithfulness of YHWH. The meaning of the phrase ûmaltem 'et'orlat lebabkem "circumcise therefore the foreskin of your heart" (10:16) bears undoubtedly a metaphorical and spiritual sense. It is difficult to accuse Moses of encouraging the Israelites to such interventions at heart, which could be compared to the surgical procedure performed on the body of the male descendants of the chosen nation. The patriarch's appeal should be interpreted in the context of the renewal of the covenant with YHWH, which probably took place in the direct perspective of entering Canaan (9:1-11:32, cf. Josh 4:1-5: 9), and understood in the category of internal admonition (marking) of the heart. Such a spiritual action provoked by an in-depth analysis of the existential situation in which the Israelites were placed due to the salvific interference of YHWH in the period of Moses and Joshua, ${ }^{37}$ and then during the return from Babylonian captivity (the final edition of the book), would have the same aim, namely to trigger a conscious and thorough transformation of their way of thinking and acting towards God. ${ }^{38}$

The theological meaning and historico-salvific determinants of the command of Moses are quite complex. First, it is necessary to recall the close connection of the rite of circumcision with the biblical concept of the covenant of Israel with YHWH and the promises of the land and offspring which He made to the patriarchs. ${ }^{39}$ In this context, the rite appears for the first time in the Bible, in the priestly tradition of Gen 17:1-27. The fact that the circumcision does not function in the Bible as a sign of the covenant of Sinai does not fit into the theological perspective of 10:12-22, although the beginning of the liberation mission by Moses takes place in the shadow of its necessity (Ex 4:24-26) and the priestly law (Lev 12:3) linked with the Sinai pericope (Ex 19:1-Num10:10)

a noncommittal cultural and religious custom. D. Block, Deuteronomy, p. 272; W. Lemke, Circumcision of the Heart, p. 299.

37 The editor precisely defines the chronology of these events in the prologue: "In the fortieth year, on the first day of the eleventh month, Moses proclaimed to the Israelites all that the LORD had commanded him concerning them" (1:3).

38 In biblical anthropology lèb "heart" is considered a center of human reason and will, responsible for making decisions and free choices. D. Block, Deuteronomy, p. 272; H. Fabry, lèb, lēbāb, pp. 399-437.

39 R. Bratcher, H. Hatton, A Handbook on Deuteronomy, p. 86; G. Hall, Deuteronomy, pp. 199-200; E. Merrill, Deuteronomy, in: P. Comfort, Cornerstone Biblical Commentary, p. 541. 
imposing it on the Israelites as a religious duty. ${ }^{40}$ The Deuteronomic theology, which lays the foundation for Yahwistic monotheism, also ignores this custom and does not encourage it to be cultivated as the way of obedience to the will of YHWH. Furthermore, instead of circumcision of male members of the community, Moses reminds the Israelites that they should deprive their hearts of the foreskin. Relying on this metaphor, circumcision acquires a universal (henceforth it can be referred to both men and women) and spiritual dimension in Israel. All those who undergo circumcision ${ }^{41}$ are additionally called by Moses to a mature and conscious choice of heart which should deepen not only their reception of this ritual, but also strengthen their sense of belonging to the people loved by YHWH and contribute to constant and responsible care for the living and personal relationship with the God of Israel.

The editor of the book does not provide reasons for reinterpretation of one of the most important religious and cultural rituals of Judaism, but relying on the content of the second part of verse 10:16 it can be concluded that it was about eliminating the routine approach to this practice which was provoked by the weakening faith of the Israelites: $w^{e}$ 'orp ${ }^{e} k e m l^{\prime}$ ' taqšu 'ôd "do not be stiff-necked any longer." (10:16b). From the very beginning circumcision was associated with the idea of a covenant with YHWH and His promises, the fulfillment of which depended on the attitude of faith and obedience to God. An example of such a model attitude in the context of circumcision was left by Abraham, Moses and Joshua (Gen 17:1-27, Ex 4:24-26, Josh 5:2-9). Unfortunately, already in the period of leaving Egypt and wandering through the desert, to which Moses refers as the Arabah dessert opposite Suph (1:1-11:32), the Israelites repeatedly opposed the will of YHWH and violated the covenant of Sinai, to which the editor of the Book of Exodus frequently refers in a metaphor of the "stiff neck" $(32: 9 ; 33: 3,5 ; 34: 9)$. The same terminology is applied by Deuteronomy $(9: 6,13 ; 10: 16)$, indicating the deep theological meaning and ultimate goal of the new understanding of the circumcision rite. Because of the "stiffness of the neck" of the Israelites, i.e. the constant and cold-hearted inability to show respect and gracious love for the salvific acts, and, above all, the idolatry (Ex 32:1-9; 32:15-33:5), which they practiced disregarding His grace

40 Circumcision also functions in the Bible as a requirement for the participation of foreigners in the worship of Israel (Ex 12:44) and the condition for the fulfillment of God's promise of the land in the period of struggles led by Joshua (Josh 5:2-9).

41 The inspired text does not explicitly prohibit the practice of external circumcision, however, 10:12-22 emphasizes the insufficiency of this practice and suggests supplementing it with a mature inner choice which can initiate the process of spiritual renewal in Israel based on the precepts of God's law. 
and faithfulness (Ex 34:1-9, 10-35), Moses in 10:12: 11:32 suggests a new formula for living the covenant with YHWH based not on the letter of the law, but on the spirit. Thus, in the context of the call for sincere faithfulness, obedience and love for YHWH, in 10:16-17 Moses demands from Israel (cf. perfectum in the sense of imperativum: ûmaltem "circumcise") a symbolic circumcision of the heart, which is meant to represent an attitude of submission to the will of God and the desire to be in a close personal relationship with Him.

In the key of the theological metaphor ${ }^{42}$ the circumcision of the heart (ûmaltem 'et'orlat lebabkem "circumcise the foreskin of your heart") should be understood as a complex and long-lasting mental, volitional and emotional process, which assumes getting rid of everything that hinders a close (spiritually intimate) relationship with $\operatorname{God}^{43}$ relying on the analogy to the physical removal of the male foreskin $\hat{u} n^{e}$ maltem 'et be'sar 'orlatkem "you shall circumcise the flesh of your foreskin (Gen 17:11). As a result of this internal process, everything that might be understood under the metaphor of "the foreskin of the heart", i.e. that prevents or hinders spiritual communion with God and opposes the patterns of behavior suggested by the Deuteronomic law (10:12$11: 32 ; 12: 1-26: 19)$ should disappear from the life of every human being who is in the covenant relationship with YHWH. This theological concept is explained by the editor of the book, who recalls a well-known biblical image of a "stiff neck". ${ }^{44}$ For this reason, the order of circumcision of the heart appears against the background of the command: $w^{e}$ 'orp ${ }^{e} k e m$ lo' taqš̂̀ 'ôd "do not make your neck stiff" (cf. Ex 32:9; 33:3,5; 34:9; Dt 9:6,13; 2Kings 17:14; 2Chr 30:8; 36:13; Jer 7:26; 17:23; 19:15; Bar 2:30; Ps 95:8). The attitude of the stiff neck, or stubbornness, disbelief and opposition of the Israelites, which marked their attitude to YHWH and Moses during their stay on the desert, becomes in this context

42 In the Bible, circumcision has several metaphorical meanings related to the prophetic idea of a new covenant and a new heart. R. Le Déaut, Le thème de la circoncision $d u$ coeur, pp. 178-205; Goldingay, The Significance of Circumcision, p. 15.

43 According to Deuteronomic theology, the uncircumcised heart (Lev 26:41, Jer 9:26; Eze 44:7-9) is inaccessible to God's will and salvific initiatives, as does the uncircumcised ear (Jer 6:10) and uncircumcised lips (Ex $6: 12,30$ ), which are incapable of listening to the word of YHWH or speaking in His name S. Driver, Deuteronomy, p. 124; E. Kalland, Deuteronomy, p. 86; J. Murray, Exodus to Ruth, p. 291; J. Tigay, Deuteronomy, pp. 107-108; J. Derouchie, Circumcision in the Hebrew Bible, p. 196.

44 The biblical image of the "hardened heart", which symbolizes the defiant, proud, unbending and unchangeable human mind and will (Ex 10:1; Dt 2:30; Sir 3:26-27; Jer 3:17; 9:13; 11:8; Eze 3:7; Mk 3:5; Eph 4:18). 
the opposite of the attitude of the circumcised heart ${ }^{45}$ postulated in 10:16-17 and the symbol of what must be permanently removed from thoughts and will of the chosen nation similar to the foreskin removed irretrievably during the rite of circumcision.

The second verse of Moses' speech about the circumcision of the heart $(10: 17)^{46}$ functions as the complement and justification of the general command expressed in 10:16 (cf. the particle kî ina causative meaning) which emphasizes the indispensability of such an action. ${ }^{47}$ It is possible that the Deuteronomic editor relies here on the original hymn which praised the power and transcendent greatness of YHWH. According to the message expressed in 10:17, the Israelites must revise their relationship with YHWH because $\mathrm{He}$ is their God and Lord, who surpasses all gods ${ }^{48}$ and people with His power and glory, and exercises justice and uncorrupted judgments over them, granting everyone according to their deeds. ${ }^{49}$ Moses believed that the image of a mighty, just and loving God should awake in the Israelites sincere fear and respect, and consequently make them worship and imitate His goodness towards the poor, orphans, widows and foreigners (10:18-20). Such an attitude would be the most appropriate response to God's salvific acts at the later stages of Israel's history (10:21-22), and at the same time a sign of a truly circumcised heart, which approaches God and the Lord with the feeling of fear, submission and faithful love. Abraham and the patriarchs left this model of attitude, which is presented in the closest context of 10:6-17 (cf. 10:15, 22). The chosen nation is called to renew the covenant in the face of the works of YHWH, especially the

45 R. Rushdoony, Deuteronomy, p. 162; J. Derouchie, Circumcision in the Hebrew Bible, pp. 196-197.

46 M. Weinfeld, Deuteronomy 1-11, p. 437; P. Craigie, The Book of Deuteronomy, pp. 206-207; D. Christensen, Deuteronomy 1:1-21:9, p. 204; C. Wright, Deuteronomy, p. 147.

47 C. Keil, F. Delitzsch, Commentary on the Old Testament, p. 899; R. Nelson, Deuteronomy, p. 137.

48 The expression of YHWH 'ĕlō hêkem hû' 'ẹlōhê hā'ělōhîm wa'ădōnê hā'ădōnîm "the LonD your God is God of gods and Lord of lords" (10:17; cf. Ps 50:1; 84:8; 95:3; 97:9; 136:2; Dn 2:47) is a classic example of the superlative in Hebrew. At the same time, it is one of the theological relics of the original version of the Yahwist monotheism, i.e. monolatry, which, apart from YHWH, allowed the existence of other gods (deities worshiped by neighboring peoples), though it emphasized His undisputed superiority. E. Merrill, Deuteronomy, pp. 203-204. This theological model underwent a radical reinterpretation only after the Babylonian captivity in the prophetic circles which denied the existence of other gods except YHWH (Is 44:6-8; 45:18-25; 46:1-13).

49 S. Sherwood, Leviticus, Numbers, Deuteronomy, p. 258. 
approaching conquest of Canaan and the final fulfillment of the promises made to the patriarchs, which Moses mentioned in 1:1-11:32 and 28:1-30:20.

However, the external sign of circumcision can no longer be only the symbol and guarantor of this renewal, as was the case of Abraham and Moses (Gen 17:1-27; Ex 4:24-26), but it must be a conscious and dictated by grateful love submission to God and His law which comes from the heart. The historical and salvific meaning of the postulate of circumcising the heart in 10:16 gives this practice a timeless, full and spiritual dimension, as it requires a complete dedication to God (circumcision) of human thoughts, will, emotions and feelings. In the face of the unquestionable manifestations of the power and grace of YHWH in Egyptian captivity and during the wandering through the desert, the Israelites no longer have any reason to continue their attitude of disbelief, distrust, resistance, and pride towards God, who revealed Himself to them through Moses and led them to freedom. Therefore, they should circumcise their own hearts and abandon the attitude of hardness (10:16), namely, relying on a thorough reflection on their current life resulting from the evident intervention of $\mathrm{YHWH}$, they should take an irrevocable decision to make Him their God and Lord, and thus fulfill the terms of the covenant with Him. ${ }^{50}$ This truth is expressed by the Deuteronomic editor by a typical formula: hālak $b^{e} k o l-d^{e} r a \overline{k a j} w$ "walking all the way of [YHWH]" (10:12a). Love and service to God $b^{e} k o l-l^{e} b a \bar{b} k \bar{a} \bar{u} b^{e} k o l-n a p s ̌ e k \bar{a}$ "with all your heart and with all your soul" (10:12b) should be expressed in their concern for the most needy (10:18-19), thus being the key message of the metaphor of the circumcision of the heart, ${ }^{51}$ and at the same time the image of the socio-religious identity of Israelite postulated in 10:12-22.52

\subsection{The Circumcision of the Heart of Israel as the Act of Faithful and Merciful God YHWH (30:6)}

The idea of circumcision of the heart returns in Deuteronomy still in 30:6, in a source material which is very similar in terms of literary form and theological content to the pericope 10:12-22. ${ }^{53}$ Verse $30: 6$ is part of a comprehen-

\footnotetext{
50 J. Smith, The Pentateuch, pp. 501-502.

51 J. Rogerson, Deuteronomy, p. 158.

52 P. Barker, The Triumph of Grace in Deuteronomy, p. 105.

53 The terminological and theological similarity of these traditions is visible, for example, in the constant reference to the idea of "today", which the reader may associate with the period of speeches made by Moses or the period of the last editor of the book. In 30:110 typical Deuteronomic chronological formulas: 'ad hajjôm hazzeh "until today", kajjôm
} 
sive epilogue of the book (29:1-34:12), which was created in a complex editing process and combines texts from different periods and writing environments. ${ }^{54}$ The announcement of the circumcision of the heart of Israel, which YHWH will accomplish in the unspecified future $(30: 6 a),{ }^{55}$ is the key truth of one of these traditions (30:1-10), which was added in the form of theological expansion to the last speech of Moses $(28: 1-69 ; 29: 1-30: 20)$ at one of the last stages of the book's edition. ${ }^{56}$ Analogically to 1:1-4:40 and 4:44-11:32, the editor and this speech by Moses focused the attention of the reader on the history and salvific conditions of the Israelites' covenant with $\mathrm{YHWH}$, its religious and legal profile and social consequences. ${ }^{57}$ The novelty of this pericope 30:1-10 in relation to its immediate and further context is that it does not refer to the past and present of the chosen nation (see e.g. the recurring motif of Israel's oppression in Egypt, its migration through the desert or the conquest of Canaan in $1: 1-11: 32 ; 28: 1-68 ; 29: 1-7,15-16)$, but to specific historical facts from the future (the period of exile). These painful experiences, in which the editors of

hazzeh "as it is today", which appear in the immediate context (cf. 29:3,9,11,12,14,17,27; 30:11,15) are missing. In the pericope 30:1-10 another formula typical of the Book of Deuteronomy appears twice: hajjôm "today" (30:2,8; cf. 30:11,15,16,18,19; 31:2,21,27; etc), which suggests its link with the Deuteronomic school.

54 Exegetes classify differently the source material collected in 29:1-34:12, but unanimously emphasize that it functions as an epilogue of the current version of the book. Without difficulty, two complementary types of sources can be distinguished in it: theological material (29:1-30:20) modeled on the content and style of the preceding speeches of Moses (cf. 1:1-4:40; 4:44-11:32; 28:1-69) and narrative material relating his last will and death (31:1-34:12). Block 29:1-30:20, which, together with a comprehensive catalog of blessings and curses $(27: 1-26 ; 28: 1-69)$, closes and comments on the set of laws 12:1-26:19. They constitute several originally separate traditions which were successively added at the subsequent stages of the edition of the book (29:1-28; 30:1-10; 30:11-14; 30:15-20). S. Driver, Deuteronomy, p. 320.

55 The exact wording of this passage is : ûmāl JHWH 'èlōhejkā 'et-lebābkā $w^{e}$ 'et-lébab zar'ek̄ "The LORD your God will circumcise your hearts and the hearts of your descendants" (30:6a).

56 Some suggest that the pericope is the continuation of 4:29-31. S. Driver, Deuteronomy, p. 328. The literary autonomy of the text 30:1-10 in its present structure is confirmed, among others, by the Masoretic annotations in the Hebrew Bible (cf. sĕtumā' in 29:28 which denotes the beginning of the new periscope and pétûh $\bar{a}^{\prime}$ ' in 30:10 which marks its ending) and the content which clearly indicates the period of Babylonian resettlement and the postexile period (cf. 30:1-2:4-5).

57 G. Beale, Myth, p. 290; P. Gordon, Deuteronomy, pp. 118-119. 
the book probably participated (29:27), are seen in the category of God's punishment for abandoning the Yahwist monotheism. ${ }^{58}$

The fundamentally different historico-salvific perspective of the editorial gloss of 30:1-10, and consequently a theological approach, is already visible in its opening. Verse 30:1 has been shaped in the form of a prophetic announcement of Moses, in the tone of blessings and curses of YHWH (30: 1a), ${ }^{59}$ which immediately underlines its credibility and inscribes it into the provisions of the covenant of Sinai. Announcing Israel's distant future, Moses first exposes to his people the humiliating realities of living in exile (30:1), which assume early breaking of the covenant with YHWH and the suspension of God's promises. The meaning of the Hebrew verb nädah "banish, push out, expel" and referring it to $\mathrm{YHWH}$ suggests that $\mathrm{He}$ will be the main perpetrator of the exile (the hiphil stem) and the stay of Israelites be kol-haggôjim "among all peoples" is the fulfillment of the curses from Sinai (28:25,32,36-37,63-64). Theological and historical meaning of 30:1-10 announces that in the future, the Israelites will ignore the warnings of Moses, violate the rules of the covenant with $\mathrm{YHWH}$, and underestimate the grace shown to their fathers. For this reason, they will lose for some time the land given to them by God and privileges of the chosen people. The editor of 30:1-10, however, does not focus on this matter, but emphasizes in each verse the theme of undying fidelity to YHWH and praises His constant disposition to forgive His disloyal people, renew the covenant they

58 Allusions to this painful future in the key of the biblical principle of God's retribution (a curse for a broken covenant) are made by the texts $(28: 36,48-47,63-68)$ already in the epilogue of the book. Relying on the terminology and theme of these late theological elaborations, it is difficult to determine whether they involve Assyrian exile (722 BC) or Babylonian exiles ( 3 resettlements in 598, 586 and 582 BC). The same idea in a slightly different form (the theological conclusion from the period of captivity put into the mouths of Israelites and representatives of foreign peoples) is expressed in 29:21-27, which warns the Israelites against renouncing the conditions of the covenant.

59 The prophetic office and mission are typical features of Moses in the Book of Deuteronomy (18:15-22; 34:10-12) and in the Pentateuch (Num 11:16-17,24-29; 12:6-8). Relying on this motif, the existing source material (cf. 29:64 and 30:1-4; 6:5,10 and 30:5-6; 7:15 and $30: 7 ; 28: 1,15$ and $30: 8 ; 7: 13 ; 28: 4,11$ and $30: 9 ; 29: 19-20,26$ and 30:10) and his own experience (the period of exile), the editor of the book created a text confirming the truthfulness of YHWH and the permanence of the covenant with Him. On the basis of the theological retrospection (vaticinium ex eventu), he refers in it to the dramatic consequences of the invasion of Shalmaneser V (2 Kings 17:3-23) and Nebuchadnezzar II (2 Kings 24:1-4,10-17; 25:1-21), but also to the happy return of the Israelites from captivity after the military successes of Cyrus (Is 40:1-41:29; cf. 2 Kings 25:27-30). The aim of this theological expansion is to evoke the truth about the justice and mercy of the God of Israel and to present the pattern of true Yahwistic piety. M. Nobile, 1-2Re, pp. 499-501. 
broke and the promises they did not keep. ${ }^{60}$ In the words of Moses, during the period of the Assyrian and Babylonian exile, and in every subsequent period of Israel's history, God will be willing to forgive the idolatrous worship and violation of His law. ${ }^{61}$ For the sake of His faithful love, YHWH will ease His anger, bring all exile to the end and bring Israel to its land even from the furthest parts of the world. ${ }^{62} \mathrm{He}$ will multiply the nation again, strengthen it, provide happiness and prosperity (30:3-5). The only condition for obtaining His forgiveness and renewal of the broken covenant will always be the return ( $r i \bar{b})$ of Israel and obedience $\left(s \bar{a} \bar{m} a^{3}\right)^{63}$ to the word of God, accompanied by a mature existential and theological reflection on the constant salvific presence of YHWH: wahăšēbōtā 'el-lebābekā "you take them to heart"(30:1b). ${ }^{64}$

The symbol of the return of Israel (šûb) to God in 30:1-10 is therefore an image, typical of the Deuteronomic theology, of the infinitely devoted heart $(l \bar{e} b)$, which listens to the voice of YHWH and is ready to fulfill His will in everything $(30: 28,10)$. The pericope, however, shows a clear anxiety and uncertainty whether such an attitude is possible at all. After reading 30:1-10, one can conclude that both Moses and subsequent editors of the book realized that love and loyalty to YHWH imposed by the Deuteronomic law $(6: 4-5 ; 10: 12,11: 13)$ are still the challenge (commitment) to be implemented. The heart of Israel has remained and still remains distant to God, regardless of His salvific activity, oppression and slavery in the period of theocracy (Ex-Judg.) and monarchy (1 Sm-2 Kings) caused by His anger for the continuous acts of idolatry and lawlessness. A representative assessment of this situation are the words of Moses 29:3: welō'-nātan JHWH lākem lēb lād'at 'ad hajjôm hazzeh "but to this day YHWH has not given you the heart that understands". And this very heart - in its individual and collective aspect (30:6) - will become the subject of

60 S. Paganini, Deuteronomio, pp. 407-408; E. Ehrenreich, Wähle das Leben, pp. 272-273 .

$6130: 1-10$ is an eschatological vision of the history of Israel and its relationship with YHWH, hence the truths communicated in it and the recalled historico-salvific facts acquire a timeless dimension. Such a perspective is indicated, among other things, by the meaning of the phrase 'attâ ûbānejkâ "you and your sons" (30:2), which in the Hebrew Bible means an undefined number of subsequent (future) generations of Israelites.

62 The term šûb expresses in this source both the idea of spiritual and religious return of Israelites to YHWH as well as their return from the exile to Canaan, which was the result of God's salvific intervention (30:2-3).

63 The irreplaceable role of these two activities in the process of Israel's reconciliation with YHWH and the reversal of the course of painful history is confirmed by repeating three times the terms expressing them in the pericope $(30: 2,8,10)$.

64 Holladay, The Root šûb, pp. 116-120. 
a special influence of God in the later stages of Israel's history. This truth is the foundation of the metaphorical reading of the command of circumcision of the heart, which appears in the culminating moment of the pericope 30:1-10: $\hat{u} m \bar{a} l$ JHWH 'ĕlōhejkā 'et-lébābkā $w^{e}$ 'et-lebab zar'ekā le'ahăbâ 'et-JHWH 'ĕlōhejkā $b^{e} k o l-l^{e} b \bar{a} b k \bar{a} \hat{u} b^{e} k o l-n a p s^{e} k \bar{a} l^{e} m a$ 'an hajjejkā "the LoRD your God will circumcise your hearts and the hearts of your descendants, so that you may love him with all your heart and with all your soul, and live" (30:6). With these words, Moses announces another salvific intervention of God and a new chapter in the history of Israel, which will bring to an end the humiliation and suffering provoked by the ongoing breaking of the covenant of Sinai $(27: 11-26 ; 28: 15-68$ and 30:1-5) and will initiate a new stage in the fulfillment of His promises and blessings. ${ }^{65}$

This future renewal of close relations with the chosen people by $\mathrm{YHWH}$ will not be a new covenant, but rather His final and effective initiative, which will make the Israelites put into practice the most important message of law, i.e. the love of their God. The words of Moses in 30:6b indicate such a nature of God's action: $l^{e}$ 'ahăbâ 'et-JHWH 'ělōhejkā $b^{e} k o l-l^{e} b a \bar{a} b k \bar{a} \hat{u} b^{e} k o l-n a p s^{e} k \bar{a}$ "so that you may love YHWH with all your heart and with all your soul". This truth indirectly confirms the content of verses 30:2,6,8,10, which refer to Israel's duty officially declared on Sinai: listening to the voice of YHWH, fulfilling His will written in law (Ex 24:7) and devoted love embracing every sphere of life (cf. $4: 29 ; 6: 5 ; 10: 12 ; 11: 13 ; 26: 16) .{ }^{66}$ On this theological level, the content of the metaphor about circumcision in the verse 30:6 does not differ much from the message of verse 10:16 and its closest context. The announcement of Moses again emphasizes the spiritual and personal nature of Israel's relationship with YHWH, to which the covenant obliges both of them. The idea of the circumcising the heart in 30:6 also goes back to the earlier history of the chosen people and brings to mind the promises given by God to the patriarchs and His salvific works during their lives and the lives of their offspring (30:5; Gen 17:1-27; Ex 3:1-4:26).

Verse 30:6, however, also sheds new light on the theological meaning and the socio-religious effects of the command of circumcision. For the first time,

65 A tangible manifestation of the future activities of YHWH will be, among others, the defeat of the enemies of Israel (30:7), its numerous offspring and material prosperity, similar to that of the Patriarchal age (30:9).

66 The mutual and lasting love of YHWH and Israel is the main motif of the book $(10: 15 ; 11: 13,22 ; 19: 9 ; 30: 6,16,20)$. Biblical sources understand this love not as the sentimental and emotional bond but as the attitude of submission, reverence and availability to YHWH originating from God's law and covenant. A. Bonora, L'amore di Dio, pp. 20-21. 
the reader of the book may learn the purpose and consequences of this mentalvolitional practice. In 30:6, Moses says that the ultimate goal of circumcision should be the love of God: $b^{e} k o l-l^{e} b \bar{a} b k \bar{a} \hat{u} b^{e} k o l-n a p \check{s}^{e} k \bar{a}$ "with all your heart and with all your soul.' This is, of course, the Deuteronomic concept of this love, i.e. the disposition of the heart which is conscious, voluntary and embracing all spheres of life leading ultimately to the union with YHWH and ensuring a peaceful and prosperous life on earth: $l^{e} m a$ 'an hajjejka "so that you may live" (30:6b; cf. 4:1; 5:16,29,33; 6:2,18; 8:1; etc.).

The theological novelty in this matter is also a radically different vision of the salvific activity of YHWH in the spiritual and religious process of transforming the mentality and conduct of the chosen people. In 30:6, Moses no longer directs the Israelites to an obliging appeal in the name of God for circumcision (cf. 10:16), but foretells his direct and effective action in this respect. The content of 30:6a clearly shows that YHWH will perform an internal intervention in the heart of Israel: ûmāl JHWH 'élōhejkā 'et-lebābkā $w^{e}$ 'et-lebab zar'ekā and this will happen in the unspecified future. The object of God's salvific initiative will be the hearts of the Israelites and the hearts of all those who desire a close relationship with $\mathrm{YHWH},{ }^{67}$ which - in the key of biblical anthropology - signify the sphere of spiritual-intellectual and emotional-volitional human activity. This significant revision in the perception of the idea of the circumcision of the heart was probably triggered by a lively theological discussion and a deep retrospection, to which the historical situation of Israel of the time was subjected in the period of the final editing of the book. In the face of the collapse of the monarchy and other important religious and social institutions in Israel and Judah, which in the prophetic and priestly circles was considered as a just punishment by God for departing from the Sinai covenant, the decision of redefining the theological profile of certain rules of Yahwist monotheism was taken. On the one hand, it was deemed necessary to uphold the validity and irrevocability of the most important provisions of the covenant with $\mathrm{YHWH}$, and, on the other hand, it was decided to re-evaluate their current understanding and shift the focus in their daily application. In the light of these modifications, the Israelites were supposed not to care so much for detail and for external correctness in fulfilling the precepts of God's law, but to pay close attention to the quality

67 The chronological sense of the phrase 'et-lebābkā $w^{e}$ 'et-lebab zar'ek̄" "your hearts and the hearts of your descendants" in 30:6 and the historico-salvific perspective of verses 30:1-5 suggest a timeless (eschatological) character of God's intervention, which will include all future generations of Israel. The biblical text does not specify whether God's activity will be characterized by a single interference or a long and multifaceted impact. 
of motivation which accompanied their actions and the consequences they had in their spiritual life.

In the spirit of these assumptions one should also understand the concept of circumcision of the heart, which the Deuteronomy presents in two stages reflecting the dynamically evolving historical and religious-cultural situation of Israel. First, the text of 10:16 tells the reader that in the face of crucial facts in the history of his own nation, e.g. entering the promised land after Egyptian captivity or returning to Canaan from Babylonian resettlement, the grounds of the religious and legal system in Israel and the theological profile of the relationship with YHWH must be redefined. The new geopolitical challenges, as well as the confrontation with other civilizations of the ancient Near East, forced to verification and constant concern about the deepening of the law and customs, which in Israel lost their theological authority and spiritual power due to the policy of religious syncretism imposed by the rulers or became solely an external and non-binding practice due to the growing crisis of religious identity. ${ }^{68}$ In these difficult circumstances, the editor of the book decides to redefine the religious and spiritual value of circumcision practiced in Israel for centuries. Referring to the authority of God and Moses, he postulates its theological re-reading, which encourages the Israelites to be more conscious and responsible in cultivating this rite, ${ }^{69}$ and in the long run to the determined and credible manifestation of their cultural heritage and religious beliefs. The shift of emphasis from the obligation to satisfy the requirements of the letter of God's law (the imperative of circumcising the body) in favor of an attitude consistent with the spirit of God's will (circumcision of the heart) marks a completely new orientation in understanding and living the socio-religious identity of the Israelite. ${ }^{70}$ This model of approach to the issue of religion obliges to constant discovery and deepening of the personal relationship with $\mathrm{YHWH}$, attachment to the tradition and faith of fathers, as well as a spiritual and non-routine approach to God's law.

68 E. Carpenter, $m w l$, p. 869; W. Baker, E. Carpenter, The Complete Word Study Dictionary, p. 580.

69 The circumcision was treated by the Israelites as a confirmation of their status as God's chosen sons, the irreversibility of their right to inherit the promises of YHWH, but also as a commitment to obey the rules of the covenant. In this key, the Bible describes Israel as: bèn $b^{e} k \bar{r} r$ "the firstborn son" of YHWH (Ex 4:22-23; Jer 31:9), mamleket köhănîm "a kingdom of priests" or gôj qādôš “a holy nation [dedicated to God]” (Ex 19:6).

70 In a similar way, this idea is interpreted by the manuscripts from Qumran, which suggest that the most important duty of the believer is to remove the foreskin of the heart (1QpHab 11:13), negative inclinations, hardness and obstinacy (1QS 5:5; Jub 1:23). R. Jewett, Romans, pp. 236-237. 
The result of the next biblical revision of the idea of circumcision of the heart can be seen in verse 30.6 , which gives it a thoroughly historico-salvific and, in some respects, eschatological dimension. Its authors, relying on an objective assessment of the history of the chosen people and personal experiences, came to the conclusion that the exact implementation of the covenant with God, whose symbol and mandatory sign in Judaism was circumcision, was very difficult, and frequently impossible without the salvific presence and support of YHWH. Therefore, in the mouth of Moses, they announced in 30:6 that it would become a fact only in the unspecified future due to the direct intervention of God. For only the salvific action of YHWH can make the Israelites listen to God's voice, obey all His commands, and love Him with all their heart and soul.

Summing up the exegetic-theological analysis of 10:16 and 30:6 in their biblical and extra-biblical literary and cultural-religious context, several general conclusions have to be formulated. Firstly, the theological and religious value of the solutions suggested by the editors of the Book of Deuteronomy should be emphasized. Re-reading one of the most representative institutions of Judaism, they developed a universal and timeless model of interpretation of circumcision, which, on the one hand, preserves the memory of the most important historico-salvific facts from the history of Israel, and, on the other hand, offers a specific pattern of religious tradition rooted in the legislation of Moses, and at the same time displays a high spiritual and theological level. Relying on the biblical and extra-biblical meaning of circumcision and the concept of the human heart (a universal symbol of human inner life and relationship with God), they created a deep metaphorical image which perfectly expresses the religious identity of Israelites based on the institutions of the Yahwistic law and covenant. Because of its theological foundation, the metaphor of the circumcised heart in Deuteronomic, priestly and prophic texts has become a pattern of interpersonal relations with YHWH for Jews and all those who seek close and personal ties with God. The idea of a circumcised heart is also an example of the perfect coherence between the external (legal) requirements defining the correct and fruitful functioning of the religious custom, and its internal (spiritual) value, which should effectively model the character and degree of piety of the Israelite and open his life to the salvific activity of God. The theological idea of a circumcised heart is one of the most profound biblical metaphors of true piety and the relationship of YHWH to Israel, which is captured in the spirit of the truth about God's election, covenant and love. It will be complemented by the Gospel of Jesus Christ and the teaching of the Church of the Apostles (Mtt 15:1-20; 23:1-36; Mk 7:1-23; Rom 2:28-29). 


\section{Bibliography}

Ancient Near Eastern Texts Relating to the Old Testament, ed. J. Prichard, Princeton 1969.

Baker W., Carpenter E., The Complete Word Study Dictionary: Old Testament, Chattanooga 2003.

Baraniak M., "Na ciele czy w duszy? Obrzezanie w polemice żydowsko-chrześcijańskiej," PJAC 4 (1; 2013), pp. 79-101.

Barker P., The Triumph of Grace in Deuteronomy. Faithless Israel, Faithful Yahweh in Deuteronomy, Waynesboro 2004.

Beale G., "Myth, History, and Inspiration. A Review Article of Inspiration and Incarnation by Peter Enns," JETS 49 (2; 2006), pp. 287-312.

Block D., Deuteronomy, NIVAC, Grand Rapids 2012.

Bonora A., "Lamore di Dio per la sua famiglia in Deuteronomio," PSV 10 (1990), pp. 9-21.

Bratcher R., Hatton H., A Handbook on Deuteronomy, New York 2000.

Brown F., Driver S., Briggs C., The Brown-Driver-Briggs Hebrew and English Lexicon, Peabody 2008.

Buchanan G., Obrzezanie, in: M. Metzger, M. Coogan, Słownik wiedzy biblijnej, Warszawa 1999, pp. 573-574.

Carpenter E., $m w l$, in: W. VanGemeren, New International Dictionary of Old Testament Theology and Exegesis, Grand Rapids 1997, vol.. 2, pp. 869-870.

Christensen D., Deuteronomy 1:1-21:9, WBC 6a, Nashville 2001.

Ciecieląg J., Żydzi w okresie drugiej świątyni 538 przed Chr. - 70 po Chr., Kraków 2011.

Cohick, L., Judaizm, wspólnota, in: J. Green, J. Brown, N. Perrin, Słownik nauczania Jezusa oraz tematów czterech Ewangelii, Warszawa 2013, pp. 329-334.

Craigie P., The Book of Deuteronomy, NICOT, Grand Rapids, 1976.

Derouchie J., "Circumcision in the Hebrew Bible and Targums: Theology, Rhetoric, and the Handling of Metaphor," BBR 14 (2; 2004), pp. 175-203.

De Vaux R., Instytucje Starego Testamentu, Poznań 2004.

Driver S., Deuteronomy, CEC, Edinburgh 1996.

Dunham D., "Naga-ed-Der Stelae of the First Intermediate Period" (Pl. XXXII, No. 84), London 1937, pp. 102-104.

Ehrenreich E., Wähle das Leben. Deuteronomium 30 als hermeneutischer Schlüssel zur Tora, BZAR 14, Wiesbaden 2010.

Forshey H., "Circumcision: An Initiatory Rite in Ancient Israel?," RQ 16 (1973), pp. $150-158$.

Fox M., “The Sign of the Covenant: Circumcision in Light of the Priestly 'ôt Etiologies," $R B 81$ (1974), pp. 557-596.

Foucart G., Circumcision (Egyptian), in: J. Hastings, Encyclopedia of Religion and Ethics, New York 1913, pp. 670-670.

Goldingay J., “The Significance of Circumcision,” JSOT 88 (2000), pp. 3-18.

Gordon R., I and II Samuel: A Commentary, LBI, Grand Rapids 1986. 
Gordon P., “Deuteronomy and the Deuteronomic School," TB 25 (1974), pp. 113-120. Hall G., Deuteronomy, CPNIVC, Joplin 2000.

Hall G., Circumcision, in: D. Freedman, The Anchor Bible Dictionary, vol. 1, New York 1992, pp. 1025-1031.

Hoenig S., "Circumcision: The Covenant of Abraham," JQR 53 (1962/63), pp. 322-334. Holladay, The Root šûb in the Old Testament with Particular References to Its Usages in Covenantal Contexts, Leiden 1958.

Isaac E., "Circumcision as a Covenant Rite," Anthropos 59 (1964), pp. 444-456.

James E., "Initiatory Rituals," in: S. Hooke, Myth and Ritual. Essays on the Myth and Ritual of the Hebrews in Relation to the Culture Pattern of the Ancient East, London 1933, pp. 147-171.

Jewett R., Romans: A Commentary on the Book of Romans, Hermeneia, Minneapolis 2007.

Jonckheere F., "La circonsion [sic] des anciens Égyptiens," Centaurus 1 (1951), pp. 212$-234$.

Keil C., Delitzsch F., Commentary on the Old Testament, Peabody 1989.

King P., "Circumcision: Who Did It, Who Didn't and Why?" BAR 32 (4; 2006), pp. 48$-55$.

Klein R., 1Samuel, WBC 10, Waco 1983.

Le Déaut R., Le thème de la circoncision du coeur (Dt. XXX 6; Jér. IV 4) dans les versions anciennes (LXX et Targum) et à Qumrân, in: J. Emerton, Congress Volume, Vienne 1980, VT. S 32, Leiden 1981, pp. 178-205.

Lemke W., "Circumcision of the Heart: The Journey of a Biblical Metaphor," in: B. Strawn, N. Bowen, A God so near. Essays on Old Testament Theology in Honor of P. Miller, Winona Lake 2003, pp. 299-319.

Livesey N., Circumcision as a Malleable Symbol, WUNT 2.295, Tübingen 2010.

Lundbom J., Deuteronomy. A Commentary, Grand Rapids 2013.

Mayer G., mûl, in: G. Botterweck, H. Ringgren, Theological Dictionary of the Old Testament, Grand Rapids 2004, vol. 8, pp. 158-162.

McConville J., The Book of Deuteronomy, in: T. Alexander, D. Baker, Dictionary of the Old Testament. Pentateuch, Downers Grove 2003, pp. 182-193.

Meade J., "Circumcision of the Heart in Leviticus and Deuteronomy: Divine Means for Resolving Curse and Bringing Blessing," SBJT 18 (3; 2014), pp. 59-85.

Meade J., "The Meaning of Circumcision in Israel: A Proposal for a Transfer of Rite from Egypt to Israel," SBJT 20 (1; 2016), pp. 35-54.

Meade J., "Circumcision of the Flesh to Circumcision of the Heart: The Developing Typology of the Sign of the Abrahamic Covenant," in: S. Wellum, B. Parker, Progressive Covenantalism: Charting a Curse between Dispensational and Covenant Theologies, Nashville 2016, pp. 127-158.

Merrill E., Deuteronomy, NAC 4; Nashville 1994.

Merrill E., Deuteronomy, in: P. Comfort, Cornerstone Biblical Commentary, Carol Stream 2008, pp. 445-674.

Murray J., “Exodus to Ruth,” in: F. Cook, Barnes' Notes. The Bible Commentary, London 1983, pp. 267-344. 
Nelson R., Deuteronomy. A Commentary, Louisville 2002.

Nobile M., 1-2Re. Nuova versione, introduzione e commento, Milano 2010.

Obrzezanie, in: L. Ryken, J. Wilhoit, T. Longman, Słownik symboliki biblijnej, Warszawa 1998, pp. 616-617.

Paganini S., Deuteronomio. Nuova versione, introduzione e commento, Milano 2011.

Propp W., "Circumcision: The Private Sign of the Covenant," BRev 20 (4; 2004), pp. 22 $-29$.

Propp W., “The Origins of Infant Circumcision in Israel," HAR 11 (1987), pp. 355-370.

Reymond, P., ḩ̌qq, in: J. Soggin, Dizionario di ebraico e aramaico biblici, Roma 1995, pp. 159-160.

Richter S., "Deuteronomistic History," in: T. Arnold, H. Williamson, Dictionary of the Old Testament. Historical Books, Downers Grove 2005, pp. 219-230.

Rogerson J., Deuteronomy, in: J. Rogerson, Eerdmans Commentary on the Bible, Grand Rapids 2003, pp. 153-173.

Rushdoony R., Deuteronomy, CP, Vallecito 2008.

Sasson J., "Circumcision in the Ancient Near East," JBL 85 (1966), pp. 473-476.

Scerbo, F., ȟsq, Dizionario ebraico e caldaico del Vecchio Testamento, Firenze 1912, p. 102.

Sherwood S., Leviticus, Numbers, Deuteronomy, Berit Olam, Collegeville 2002.

Schreiner T., Obrzezanie, in: G. Hawthorne, R. Martin, D. Reid, Słownik teologii św. Pawła, Warszawa 2010, pp. 539-542.

Sherwood S., Leviticus, Numbers, Deuteronomy, Berit Olam, Collegeville 2002.

Smith A., The Book of the Deuteronomy, CBSC, Cambridge 1918.

Smith J., The Pentateuch, OTSS, Joplin 1993.

Steiner R., "Incomplete Circumcision in Egypt and Edom: Jeremiah [9,24-25] in the Light of Josephus and Jonckheere," JBL 118 (3; 1999), pp. 497-505.

Stern D., Komentarz żydowski do Nowego Testamentu, Warszawa 2008.

Tigay J., Deuteronomy, JPS Torah Commentary, Philadelphia 1989.

Wallis G., ḩ̌sq, in: G. Botterweck, H. Ringgren, Theological Dictionary of the Old Testament, Grand Rapids 2004, vol. 5, pp. 261-263.

Weinfeld M., Deuteronomy and the Deuteronomic School, Oxford 1972.

Weinfeld M., Deuteronomy 1-11. A New Translation with Introduction and Commentary, New Haven 1991.

Williamson P., Circumcision, in: T. Alexander, D. Baker, Dictionary of the Old Testament: Pentateuch, Downers Grove, 2003, pp. 122-125.

Wright C., Deuteronomy, UBCS, Grand Rapids 1996. 